\title{
Plant-based Complementary and alternative medicine used by breast cancer patients at the Hospital Universitario San Ignacio in Bogotá, Colombia
}

\author{
Luz Angela Diaz ${ }^{1}$, Lilian Torregrosa ${ }^{2}$, Luisa Benítez ${ }^{3}$, Marcela Mercado ${ }^{3}$, Susana Fiorentino ${ }^{1 \times}$.
}

Received: 11-09-2012 Accepted: 20-11-2012 Published on line: 4-12-2012

Edited by Alberto Acosta

Summary. The present study estimates the frequency of the use of plant-based Complementary and Alternative Medicine (CAM) by breast cancer patients. From June to December of 2011, a self-administered questionnaire was given to 404 breast cancer patients receiving outpatient therapy at the Javeriana Oncology Center of the Hospital Universitario San Ignacio in Bogotá. The prevalence of patient CAM use was 57\%, out of which $76 \%$ was based on plants like anamú, aloe, red fruits and soursop. Sixty-five percent of the patients had a positive perception of using medicinal plants and 57\% used them simultaneously with the oncologist recommended allopathic treatment. We concluded that the frequency of CAM use in breast cancer patients at the Javeriana Oncology Center is within the prevalence range reported worldwide, despite differences in CAM types and frequencies. The high rates of plant-based CAM use without physician consent, brings about the lack of assessment of the synergic or antagonistic effects of CAM therapies on the allopathic treatment of breast cancer and evaluation of the antitumor and immunomodulatory potential of the traditionally used plants.

Keywords: Complementary and Alternative Medicine, breast cancer, plant-based therapy, anamú and soursop

1 Immunobiology and Cell Biology Group. Pontificia Universidad Javeriana. Bogotá, Colombia.

2 General Surgery and Specialties Group Hospital Universitario San Ignacio Bogotá, Colombia.

3 Epidemiologist. Infectious Diseases Group Pontificia Universidad Javeriana. Bogotá, Colombia.
Uso de medicina alternativa y complementaria basada en plantas, por pacientes con cáncer de seno en el Hospital Universitario San Ignacio en Bogotá, Colombia. Resumen. Durante este estudio se buscó determinar la frecuencia de uso de medicina alternativa y complementaria (CAM) basada en plantas, en pacientes con cáncer de seno. Se realizó por medio de encuestas en pacientes con cáncer de seno que asistieron a consulta externa al Centro Javeriano de Oncología del Hospital San Ignacio en Bogotá en los meses de Junio a Diciembre del 2011. De las 404 encuestas aplicadas en mujeres con cáncer de seno, el 57\% consumieron algún tipo de CAM para el cáncer de seno y de estos el $76 \%$ consumieron plantas medicinales como el anamú, la sábila, los frutos rojos y la guanábana, entre otros. El 65\% de los pacientes tuvieron una percepción positiva frente al consumo de las plantas medicinales y el $57 \%$ de los usuarios de terapias basada en plantas, la uso simultáneamente al tratamiento alopático recomendado por el médico oncólogo. Concluimos que la frecuencia de uso de CAM en pacientes con cáncer de seno del Centro Javeriano de Oncología en Bogotá, esta dentro del rango de prevalencia reportado mundialmente, aunque existen diferencias marcadas en los tipos y frecuencias de CAM consumidas. La alta proporción de pacientes que usan CAM basada en plantas sin discutirlo con el médico oncólogo, tiene como consecuencia la falta de evaluación con respecto a los efectos sinérgicos o antagónicos de estas terapias frente al tratamiento alopático del cáncer de mama; así como el potencial antitumoral y inmunomodulador real de las plantas usadas de manera tradicional por lo pacientes oncológicos.

Resumo. O presente estudo se propôs a avaliar a frequência da utilização de Medicina Alternativa e Complementar (CAM) baseada em plantas por pacientes com câncer de mama. Um questionário autoadministrado foi dado a 404 pacientes com câncer que frequentaram a terapia ambulatória no Centro Javeriano de Oncologia do Hospital Universitário San Ignacio, em Bogotá entre junho e dezembro de 2011. O consumo de algum tipo de CAM por parte dos pacientes foi de $56 \%$. 76\% selecionaram plantas como anamú, aloé , frutos vermelhos e graviola. Os resultados foram que $65 \%$ dos pacientes tiveram uma percepção positiva de usar plantas medicinais. 57\% dos pacientes utilizaram o tratamento alopático simultaneamente. Conclui-se que a freqüência do uso de CAM em pacientes com câncer de mama no Centro Javeriano de Oncologia está dentro da faixa de prevalência registrada no mundo, embora com diferenças nos tipos de CAM e freqüências. A elevada taxa de pacientes que usam CAM baseada em plantas sem consentimento médico é o resultado da falta de respeito ou avaliação dos efeitos sinérgicos o antagônicos de terapias CAM contra o câncer da mama, bem como o potencial tratamento alopático antitumoral e imunomoduladora das plantas reais utilizados tradicionalmente. 


\section{Introduction}

The United States National Cancer Institute defines CAM as a group of healthcare systems, practices and therapies not based on conventional or allopathic medicine and therefore excluded from medical school programs and public health systems. Alternative medicine replaces conventional medical intervention while complementary medicine is used conjointly with it. According to the United States National Center for Complementary and Alternative Medicine (NCCAM) CAM types are: mind-body therapies (meditation), energy therapies (electromagnetic therapy), alternative medical systems (homeopathy), manual healing therapies (acupressure) and biologically based therapies (plants) (1, 2).

The use of plant-based therapies by breast cancer patients depends on cultural background. A survey in northwestern Turkey established that breast cancer patients prefer herbal therapies (67\%) over other CAM types (3), while in Canada and Australia the frequency of herbal therapy use was only $20 \%(4,5)$.

Implications in the treatment effectiveness of conventional therapies may exist when plant-based therapies are used without a physician's explicit consent, as they may interact antagonistically or synergistically with conventional therapies. An example of an antagonistic interaction is the use of St. John's herbal infusions (Hypericum perforatum), which cause irinotecan plasma levels to dramatically decrease causing the loss of antitumor activity (6). In contrast, curcuma (Curcuma longa), a traditional Indian and Chinese medicine, enhances antitumor activities (7).

Breast cancer is the most common tumor in women worldwide with an increase of 23\% (1.38 million) of new cases per year. It was accountable for $14 \%(458,000)$ of all cancer deaths in 2008 (8). In Colombia, breast cancer ranks second in frequency with an incidence rate of 31 per 100,000 women as reported in 2008, lower in comparison to the United States, where the incidence rate is 77 per 100,000 women. According to Bogota's National Cancer Institute there were 551 new cases in 2009 of primary breast cancer, corresponding to $10 \%$ of all new registered cancer cases (9).

In the United States, CAM use by breast cancer patients reaches $75 \%(10)$ and in disease-free survivors, it rises to $83 \%(11,12)$, a higher incidence than with any other types of cancers (13). Because reports on CAM use by cancer patients in Colombia is scarce, our study seeks to estimate the frequency of plant-based CAM use whether alone or together with conventional therapy in breast cancer patients receiving outpatient therapy at the Javeriana Oncology Center of the Hospital Universitario San Ignacio in Bogota. Additionally, we sought to learn about the plants most commonly used by patients and the relationship between these herbal therapies and the patient's perception of their general state of health.

\section{Material and methods}

Patients Design: A cross-sectional observational study based on a survey completed by patients attending the Javeriana Oncology Center of the Hospital Universitario San Ignacio's in Bogota.

Participants: The science and ethic committees of the Medical and Science Faculties of the Pontificia Universidad Javeriana approved the survey protocol. Surveys were issued to patients receiving outpatient treatment at the Javeriana Oncology Center (JOC) of the Hospital Universitario San Ignacio in Bogota, from June through December 2011. The participating patients were over 18 years old, and diagnosed with breast cancer regardless of its stage. The participants voluntarily signed a consent and information form to participate in this study.

Questionnaire: The survey had three sections: the first section covered social demographic characteristics such as age, marital status, gender, socioeconomic status, educational level and current occupation. The second section focused on the disease and items such as clinical stage, time of diagnosis and treatment type. The third section addressed the use of CAM as a treatment for breast cancer and if it was used alone or together with other therapies, specifying plant type, length of treatment, procedure and frequency of use as well as its financial costs. The section also recorded who recommended its use, whether it was used under physician's consent and the physician's view about its use, as well as the patient's mental perception of its use. 
Data analysis: Socio-demographic and clinical variables of CAM users and non-users were compared. The independent variables were calculated by differences in rate and continuous variables by the mean \pm standard deviation. The significance level established was 5\%. SPSS 19 and Statistix 9 software was used for the database and statistic analysis.

\section{Results}

Socio demographic and clinical characteristics: Four hundred and four patients fulfilled the inclusion criteria. All the patients were female with a median age of $58.6 \pm 11.9$ years (range 28-90 years); 82.9\% (335/404) were mixed-race; 48.5\% (196/404) were married or cohabited; 70.2\% (284/404) were within the 2 and 3 socioeconomic strata; $54.2 \%(219 / 404)$ had elementary and secondary education; and $35.4 \%$ (143/404) were housewives. The average time since the original diagnosis was 52.5 months (1 - 432 months) for each patient. Clinically, 64.6\% (261/404) were at clinical stage II and III, with $11 \%$ who had relapsed. Among the treatments, $90.5 \%$ (366/404) of the patients had undergone surgery, $68.0 \%$ (275/404) followed with chemotherapy, $62.1 \%(251 / 404)$ followed by radiotherapy and 59.4\% (240/404) with hormonal therapy.

Use of Complementary and Alternative Medicine (CAM): CAM therapy was used as treatment by $57.1 \%(231 / 404)$ of the surveyed patients (Table 1) and in $77.4 \%(179 / 404)$ of these cases, the patients' friends or relatives were the promoters of CAM usage. In $75.7 \%(175 / 404)$ of the surveyed patients, the use of CAM was without physician consent; yet, when it was openly discussed with the physicians, $75 \%(42 / 56)$ of them approved its use.

The different CAM therapies were grouped according to the United States NCCAM classification. The therapies most used were: Plants-based therapies $77 \%$, prayer $74 \%$, vitamin supplements $25 \%$, bioenergetics $14 \%$ and homeopathy $9 \%$.

There were no significant differences in the use of CAM, as related with socio-demographic variables such as age, marital status, race, schooling, and occupation; however, there were significant differences in the use of CAM according to socioeconomic strata where its use was higher in strata 3 and $4(p<0.001)$ compared to strata 5 and $6(\mathrm{p}<0.001)$ (Table 1).

Table 1. Distribution of sociodemographic characteristics in patients with breast cancer who use or not CAM.

\begin{tabular}{|c|c|c|c|}
\hline Features & $\begin{array}{l}\text { CAM users } \\
(n=231)\end{array}$ & $\begin{array}{c}\text { CAM non-Users } \\
(\mathrm{n}=173\end{array}$ & $\mathbf{p}$ \\
\hline $\begin{array}{l}\text { Age (Years, SD) } \\
\text { Age range (Years) }\end{array}$ & $\begin{array}{l}57(+/-11) \\
28-90\end{array}$ & $\begin{array}{l}61(+/-12) \\
29-90\end{array}$ & 0.109 \\
\hline $\begin{array}{l}\text { Marital Status n (\%) } \\
\text { Single } \\
\text { Married } \\
\text { Others (unmarried partners, divorced, widowed) }\end{array}$ & $\begin{array}{ll}51 & (22.1) \\
91 & (39.4) \\
89 & (38.5)\end{array}$ & $\begin{array}{ll}42 & (24.3) \\
67 & (38.7) \\
64 & (36.9)\end{array}$ & $\begin{array}{l}0.974 \\
0.689 \\
0.833\end{array}$ \\
\hline $\begin{array}{l}\text { Race } \mathbf{n}(\%) \\
\text { Caucasian } \\
\text { Mestizo } \\
\text { Indian } \\
\text { Afro-Colombian } \\
\text { Gypsy }\end{array}$ & $\begin{array}{l}19(8.2) \\
197(85.3) \\
10(4.3) \\
5(2.2) \\
0(.0)\end{array}$ & $\begin{array}{l}24(13.9) \\
138(79.8) \\
3(1.7) \\
7(4.0) \\
1(0,2)\end{array}$ & $\begin{array}{l}0.185 \\
0.097 \\
0.239 \\
0.420 \\
0.884\end{array}$ \\
\hline $\begin{array}{l}\text { Socioeconomic stratum } \mathbf{n}(\%) \\
\text { Stratum } 1 \text { y } 2 \\
\text { Stratum } 3 \text { y } 4 \\
\text { Stratum } 5 \text { y } 6\end{array}$ & $\begin{array}{l}75(32.4) \\
143(61.9) \\
13(5,62)\end{array}$ & $\begin{array}{ll}50 & (28.9) \\
47 & (27.1) \\
73 & (42.1)\end{array}$ & $\begin{array}{l}0.510 \\
<0.001 \\
<0.001\end{array}$ \\
\hline $\begin{array}{l}\text { Educational level n (\%) } \\
\text { None } \\
\text { Primary school } \\
\text { Secondary (high) school } \\
\text { Technique, University degree, postgraduate. }\end{array}$ & $\begin{array}{l}1(0,4) \\
50(6.5) \\
72(31.1) \\
108(46.7)\end{array}$ & $\begin{array}{l}3(1.7) \\
50(28.9) \\
47(27.1) \\
73(42.1)\end{array}$ & $\begin{array}{l}0.424 \\
0.119 \\
0.445 \\
0.417\end{array}$ \\
\hline $\begin{array}{l}\text { Occupation } \mathbf{n}(\%) \\
\text { Housewife } \\
\text { Employed } \\
\text { Independent } \\
\text { Retired } \\
\text { Others (Student, unemployed). }\end{array}$ & $\begin{array}{ll}78 & (33.8) \\
49 & (21.2) \\
35 & (15.2) \\
61 & (26.4) \\
8 & (3.4)\end{array}$ & $\begin{array}{l}65(37.6) \\
36(20.8) \\
20(11.6) \\
43(24.9) \\
9(5.2)\end{array}$ & $\begin{array}{l}0.492 \\
0.811 \\
0.980 \\
0.370 \\
0.541\end{array}$ \\
\hline
\end{tabular}


No significant differences were found within the clinical variables (Table 2 ) such as time since diagnosis, disease level and patients receiving radiotherapy or hormone therapy. Meanwhile, the use of CAM by patients at clinical stage I $(\mathrm{p}=0.024)$ was less than in patients at stage III ( $\mathrm{p}=0.030)$. The same trend was observed in patients who had undergone surgery $(p<0.001)$ or received chemotherapy $(\mathrm{p}<0.001)$ (Table 2$)$.

Tabla 2. Distribution of clinical characteristics, current status of the disease and received allopathic treatment in patients users and non-users of CAM

\begin{tabular}{|c|c|c|c|}
\hline Features & $\begin{array}{l}\text { CAM users } \\
(n=231)\end{array}$ & $\begin{array}{l}\text { CAM non-Users } \\
\qquad \mathbf{n}=173\end{array}$ & $\mathbf{p}$ \\
\hline $\begin{array}{l}\text { Time since diagnosed (months, SD) } \\
\text { Range (Months) }\end{array}$ & $\begin{array}{l}52(+/-56) \\
1-347\end{array}$ & $\begin{array}{l}53(+/-63) \\
1-431\end{array}$ & 0.866 \\
\hline $\begin{array}{l}\text { Clinical State } \mathbf{n}(\mathbf{0}) \\
\text { State } 0 \\
\text { State I } \\
\text { State II } \\
\text { State III } \\
\text { State IV } \\
\text { No data }\end{array}$ & $\begin{array}{ll}7 & (3.0) \\
30 & (13.0) \\
86 & (37.2) \\
73 & (32.6) \\
20 & (8.7) \\
15 & (6.5)\end{array}$ & $\begin{array}{ll}9 & (5.2) \\
38 & (22.0) \\
65 & (37.6) \\
37 & (21.4) \\
12 & (6.9) \\
12 & (6.9)\end{array}$ & $\begin{array}{l}0.395 \\
0.024 \\
0.973 \\
0.030 \\
0.654 \\
0.980\end{array}$ \\
\hline $\begin{array}{l}\text { Current disease status } \mathbf{n}(\mathbf{0}) \\
\text { Attends for systemic relapse } \\
\text { Attends for local relapse }\end{array}$ & $\begin{array}{l}18(7.8) \\
14(6.1)\end{array}$ & $\begin{array}{ll}8 & (4.6) \\
7 & (4.0)\end{array}$ & $\begin{array}{l}0.280 \\
0.499\end{array}$ \\
\hline $\begin{array}{l}\text { Received surgery } \mathbf{n}(\mathbf{0}) \\
\text { Yes (MRM/BCS a) }\end{array}$ & 197 (85.2) & $169(97.6)$ & $<0.001$ \\
\hline $\begin{array}{l}\text { Received chemotherapy n (\%) } \\
\text { Yes }\end{array}$ & $176(76.2)$ & 99 (57.2) & $<0.001$ \\
\hline $\begin{array}{l}\text { Received radiotherapy } \mathbf{n}(\mathbf{\%}) \\
\text { Yes }\end{array}$ & $145(62.7)$ & $106(61.2)$ & 0.838 \\
\hline $\begin{array}{l}\text { Received hormonal therapy } \mathbf{n}(\mathbf{0}) \\
\text { Yes }\end{array}$ & $141(61.0)$ & 99 (57.2) & 0.502 \\
\hline
\end{tabular}

*The percentage of allopathic treatment exceeds 100\%, because patients receive a combination of these.

a. $\mathrm{MRM}=$ Modified radical mastectomy (Including axillary dissection). BCS $=$ Breast conserving surgery (Including axillary dissection).

Use of plant-based CAM: The medicinal plants were grouped under two categories: herbs and fruits. In the first group included anamú (Petiveria alliacea), aloe (Aloe vera), green tea (Camellia sinensis) and calendula (Calendula officinalis) (Table 3). 
Table 3. Distribution of types of herbs consumed by patients with breast cancer $\mathrm{n}(\%)$.

\begin{tabular}{lll}
\hline Anamu & $60(33.8)$ \\
Aloe & $57(32.2)$ \\
Green tea & $10(5.6)$ \\
Marigold & $10(5.6)$ \\
Ganoderma & 9 & $(5.0)$ \\
Broccoli & 5 & $(2.8)$ \\
Chamomile & 5 & $(2.8)$ \\
Asparagus & 5 & $(2.8)$ \\
Celery & 5 & $(2.8)$ \\
Spinach & 5 & $(2.8)$ \\
Cidrón & 5 & $(2.8)$ \\
Ginger & 3 & $(1.6)$ \\
Peppermint & 3 & $(1.6)$ \\
Lentil & 3 & $(1.6)$ \\
Pepper & 3 & $(1.6)$ \\
Others* & $<2(<1.1)$ \\
\hline
\end{tabular}

* Others herbs like anise, aranto, artichoke, basil, beets, drago's blood, bloodroot, bore, calaguala, cañabrava, cat's claw, cauliflower, chlorophyll, cinnamon, coffee leaf, confrey, cucumber, dandelion, dividivi, eggplant, flax, flower Jamaica, frailegon, gabriologo, garlic, guatila, hoja santa, hojaracin, kombucha, lemon grass, lemon, melissa, mint, mother in law tongue, nettle, parsley, pumpkin, radishes, rosemary, rye, silymarin, spirulina, tea cannabis, tomato, valerian, vanishing, verbena, wheat germ and zen leaves.

The second group, fruits such as agraz (Vaccinium meriodionale sw), strawberry (Fragaria chiloensis), blackberry (Rubus glaucus), soursop (Annona muricata), isabella grape (Vitis vinifera) and noni (Morinda citrifolia) (Table 4).

After using the plant-based therapies, $65 \%$ of patients had a positive overall perception of their condition and even presented health improvements.

The use of plants as part of the treatment was perceived positively by $58 \%$ of the patients when comparing mental perception and clinical stages.

No significant differences were found between

Tabla 4. Mental perception according to the type of herb or fruit consumed by patients with breast cancer.

\begin{tabular}{|c|c|c|c|c|}
\hline Plant type & $\begin{array}{c}\text { Radically } \\
\text { improved n (\%) }\end{array}$ & $\begin{array}{l}\text { Some positive } \\
\text { change n (\%) }\end{array}$ & $\begin{array}{c}\text { No changes } \\
\text { n }(\%)\end{array}$ & $\begin{array}{c}\text { Radically } \\
\text { worsened n (\%) }\end{array}$ \\
\hline \multicolumn{5}{|l|}{ Herbs } \\
\hline Anamu $(n=60)$ & $23(38.3)$ & $16(26.7)$ & $20(33.3)$ & $1(1.7)$ \\
\hline Aloe $(n=57)$ & $25(43.9)$ & $15(26.3)$ & 17 (29.8) & $0(0.0)$ \\
\hline Green tea $(n=10)$ & $5 \quad(50.0)$ & $2 \quad(20.0)$ & $3 \quad(30.0)$ & $0(0.0)$ \\
\hline Marigold $(n=10)$ & $2(20.0)$ & $4 \quad(40.4)$ & $4 \quad(40.0)$ & $0(0.0)$ \\
\hline \multicolumn{5}{|l|}{ Fruits } \\
\hline Berries $(n=59)$ & $27(45.7)$ & $15(25.4)$ & 17 (28.8) & $0(0.0)$ \\
\hline Soursop $(n=42)$ & $17(40.5)$ & $10(23.8)$ & $15(35.7)$ & $0(0.0)$ \\
\hline Isabella grape $(n=29)$ & $10(34.5)$ & $10(34.5)$ & $9 \quad(31.0)$ & $0(0.0)$ \\
\hline Noni $(n=19)$ & $10(52.6)$ & $3 \quad(15.8)$ & (31.6) & $0(0.0)$ \\
\hline
\end{tabular}

patients using CAM simultaneously with allopathic treatment and those not using simultaneous CAM- allopathic treatment ('Table 5).

Users of plant-based CAM usually purchase the

Tabla 5. Distribution of perception of the use of plant-based CAM as a treatment for breast cancer, according to the use or no simultaneously with the treatment prescribed allopathic.

Perception in patients Simultaneously used allopathic medicine and plant-bases using CAM

CAM as a treatment for breast cancer.

\begin{tabular}{llll} 
& Yes $(\mathrm{n}=102)$ & No $(\mathrm{n}=75)$ & $\mathrm{p}$ \\
\hline Radically improved & $45(44.1)$ & $25(33.3)$ & 0.147 \\
Some positive change & $28(27.5)$ & $18(24.0)$ & 0.604 \\
No changes & $29(28.4)$ & $31(41.3)$ & 0.079 \\
Radically worsened & $0(0.0)$ & $1(1.3)$ & 0.242 \\
\hline
\end{tabular}


plants from marketplaces or supermarkets $(79 \%)$, from health food stores $(14 \%)$, or obtain them from home grown cultures and physician's offices (7.0\%). The most common method of ingestion is either fresh or in juice form $50.8 \%$ and as a leaf infusion

On average the plant-based CAM was used $(28.8 \%)$ for 19.7 months (1-132 months) and the average monthly cost was 33,176 Colombian (Table 6).

Table 6. Origin and form of preparation of plant-based CAM.

\begin{tabular}{|c|c|}
\hline Feature & $\begin{array}{c}\text { Frequency } \\
(\mathbf{n}=177)^{*}\end{array}$ \\
\hline Origin of the plant & $\mathrm{n}=(\%)$ \\
\hline Market square/Super- & $140(79.1)$ \\
\hline market & $25(14.1)$ \\
\hline Naturist store & $14(7.9)$ \\
\hline Homegrown & $14(7.9)$ \\
\hline Medical Office & $5(2.8)$ \\
\hline Imported & $3(1.6)$ \\
\hline Pharmacy & $2(1.1)$ \\
\hline \multicolumn{2}{|l|}{ Catalog } \\
\hline Forms of preparation & $90(50.8)$ \\
\hline Fresh or juice & $51(28.8)$ \\
\hline Leaf infusion & $11(6.2)$ \\
\hline Whole plant infusion & $11(6.2)$ \\
\hline Syrup & $5(2.8)$ \\
\hline Tablets & $3(1.6)$ \\
\hline Drops & $10(5.6)$ \\
\hline \multicolumn{2}{|l|}{ Others $^{a}$} \\
\hline Consumer frequency & $92(51.9)$ \\
\hline All days 1-2 times & 33 (18.6) \\
\hline All days 3-4 times & $22(12.4)$ \\
\hline Per week over 3 times & $17(9.6)$ \\
\hline 1-2 times weekly & $13(7.3)$ \\
\hline All days above 5 times & \\
\hline
\end{tabular}

*The $\sum$ of percentage exceeds $100 \%$, because several patients used simultaneously. a Other forms of preparation to include: plants extract, roots infusion, dust, kneading and sun-dried and topical form.

\section{Discussion}

The use of CAM by breast cancer patients at the JCO in Bogotá was 57\%, lower than the results in a previous study in Colombia (73\%) (1). Still, CAM prevalence reports in breast cancer patients vary broadly (27-98\%) (14-16), probably due to the lack of clear definitions about the concept of CAM (17) and the different survey methodologies (18). Most of the patients surveyed were motivated to use CAM through the suggestions of friends or relatives, akin to the results of previous studies $(3,19-21)$. However, mass media also exerts an important influence in the use of CAM $(5,21)$, suggesting that CAM is still seen as a safe therapeutic alternative, although this is not necessarily true in all cases.

Similarly to previous reports, $75.7 \%$ of the patients participating in our survey used CAM without their doctor's knowledge $(1,22)$. The failure in communication between patients and doctors, regarding herbal therapies, may be due to scarceness of scientificinformation available to the clinician-community regarding this subject, which hinders the doctor from discussing these options with the patient, who in turn, is discouraged from discussing alternate therapies. In contrast, in the United States, women with advanced stages of breast cancer $(60 \%)$ discuss CAM use with their physician, possibly because CAM has become a branch of the NIH and the creation of the NCCAM has allowed alternative therapies to have a status within the medical community. Moreover, patients seem to be more aware of the possibility of interactions between therapies and therefore solicit advice (19). The need to promote an open culture is therefore evident to encourage patients to request physician's advice in these matters and to participate in the evaluation of the safeness and effectiveness of CAM therapies (20, 23).

In our study, patients preferred biological therapies (plants or dietary supplements) to mind-body therapies (prayers), energy based therapies (bioenergy) and alternative medical systems (homeopathy and acupuncture.) In other countries nutritional supplements, plants and spiritual practices are the most common therapies (Table 7). 
Table 7. Distribution of types of CAM according to the NCCAM classification $(\mathrm{n}=231)$.

\begin{tabular}{|c|c|c|}
\hline \multicolumn{3}{|c|}{ Biological origin $n(\%)$} \\
\hline Based Plants & 177 & $(76.6)$ \\
\hline Dietary supplements & 59 & $(25.5)$ \\
\hline Based animals & 8 & $(3.4)$ \\
\hline \multicolumn{3}{|c|}{ Mind-body medicine $\mathrm{n}(\%)$} \\
\hline Religion ( $n=172$ ) & 172 & $(74.4)$ \\
\hline $\operatorname{Yoga}(n=4)$ & 4 & $(1.7)$ \\
\hline Musical therapy $(n=2)$ & 2 & $(0.8)$ \\
\hline \multicolumn{3}{|c|}{$\begin{array}{l}\text { Alternative medical systems n } \\
(\%)\end{array}$} \\
\hline Homeopathy $(\mathrm{n}=20)$ & 20 & $(8.6)$ \\
\hline Acupuncture $(n=3)$ & 3 & $(1.2)$ \\
\hline \multicolumn{3}{|l|}{ Based Energy n (\%) } \\
\hline Bioenergetics $(n=32)$ & 32 & $(13.8)$ \\
\hline Ozone therapy $(n=1)$ & 1 & $(0.4)$ \\
\hline
\end{tabular}

Socio-demographically, there is a higher tendency to use CAM in patients belonging to socioeconomic strata 3 and $4(\mathrm{p}<0.001)$ compared to strata 5 and 6 $(\mathrm{p}<0.001)$. The latter contradicts reports associating married young women with high income and high educational levels with the use of $\operatorname{CAM}(4,24-27)$. However, there are also reports of less CAM use in women with high education levels participating in phase I clinical trials in the United States (28).

The percentage of non-CAM users in clinical stage I ( $p=0.024)$ was significantly higher compared to patients in clinical stage III ( $p=0.030)$. However, to date there are no reports associating tumor clinical stage and CAM usage (14, 29). By analyzing the treatment type and CAM use, we found that more chemotherapy patients used CAM compared to patients not using it ( $\mathrm{p}<0.001)$, in agreement with reports in the literature $(3,5,14,20,24,28)$. Various literature reports show no relation between surgery and CAM use $(3,30,31)$; here, we found a significant number of CAM users in patients who had undergone surgery ( $p<0.001)$.

In accordance with literature reports (1), 76.6\% of the patients used plant-based CAM. Although botanical identification of the plants consumed by the patients was not carried out, we believe that the common names reported by the patients, correspond to the scientific names. The most common plant was anamú (Petiveria alliacea), a plant known to have anti-cancer and anti-tumor attributes, it disrupts the tumor cell's cytoskeleton, inducing cell cycle arrest and causing apoptotic cell death, according to previous results by our group [32]. The plant polar compounds can also induce tumor cell death through mitochondria-dependent mechanisms and by down regulating HSP70 expression. Dibenzyl trisulphide (DTS) is a compound reported to be responsible for plant biological activity (32). However, our results show that the active plant fraction has at least 58 different compounds detected by HPLC and active subfractions do not contain DTS as the main component (unpublished data).

Another plant of common use among the surveyed patients was Aloe vera, a plant with many reported biological activities (33). Recently in a phase III clinical study where aloe was used as moisturizer to reduce radiation side effects such as skin peeling and pain in patients undergoing radiotherapy (34) the fibroblast cellular structure improved, increasing collagen secretion and contributing to the healing process (35).

An additional plant used by our patients was green tea (Camellia sinensis), a beverage consumed worldwide, rich in tea catechins specifically epigallocatechin-3-gallate (EGCG) and epigallocatechin (EGC), compounds with many cancer chemopreventive attributes including antioxidant, anti-inflammatory, anti-proliferative and anti-angiogenic properties. Additionally, it has been found to prevent estrogen to receptor binding in tumor cells (36) and to inhibit aromatase, an enzyme that mediates the conversion of androgens to estrogens in rats (37). In cross-sectional studies green tea was associated with reduced serum levels of estrogens in premenopausal women in Japan (38) and postmenopausal women in Singapore (39), suggesting it may favorably alter hormone levels associated with risk of breast cancer.

Our study also found that Calendula (Calendula officinalis) was a plant commonly used by the patients. In phase III clinical trials, the plant has displayed properties to prevent acute dermatitis and to lessen pain in postsurgical cancer patients subjected to radiation (40). Furthermore, the plant has shown anti-proliferative and cytotoxic properties over human and murine tumor cell lines by inducing cell cycle arrest in G0/G1 and apoptosis through 
caspase 3 activation. In addition, it can induce activation and proliferation of human peripheral blood lymphocytes and NK cells (41).

Patients' fruit preferences included sour grapes (Vaccinium meriodionale sw), strawberries (Fragaria chiloensis), blackberries (Rubus glaucus), sarsaparilla (Smilax aspera L), cherries (Prunus avium) and blueberries (Vaccinium oxycoccus). Due to the fruit's high content of phenols, flavonoids, tannins and anthocyanins they may have antioxidant, anti-cancer, anti-neurodegenerative and anti-inflammatory properties (42). Several studies show growth inhibition of tongue (CAL-27), breast (MCF-7), colon (HT-29, HTC116) and prostate (LNCaP) tumor cell lines when treated with strawberry, blackberry, raspberry and blueberry extracts (42-44).

Another fruit used among cancer patients was soursop, guanábana or graviola (Annona muricata), a fruit reported to have antiviral, antioxidant $(45,46)$ and anti-tumor properties. Soursop extract has been known to down-regulate epidermal growth factor receptor (EGFR) expression, an oncogene overexpressed in breast cancer associated with poor prognosis and drug resistance. It also known to inhibit breast cancer cells (MDA-MB-468) growth and xenografts in nude mice (47).

Grape seed extract (Vitis vinifera), due to its procyanidines content, inhibits the expression and activity of the enzyme aromatase in mice with MCF7 xenografts (48). Another study revealed that grape seed extract had a synergistic effect with doxorubicin in inhibiting MCF-7 and MDA-MB468 tumor cell lines growth (49). Grape's polyphenols have been reported to have chemopreventive activity that modulates processes such as cell cycle, apoptosis, inflammation, angiogenesis and metastasis $(50,51)$.

Lastly, noni (Morinda citrifolia) has demonstrated antioxidant properties associated to the content in phenols, iridoids and ascorbic acid. Its antiinflammatory activity is attributed to nitric oxide and prostaglandin E inhibition in activated J774 cells (52). Wang et al have indicated other noni biological activities namely antibacterial, antiviral and antitumor (53). Noni can also be chemopreventive, reducing cancer risk in smokers by inhibiting the formation of DNA adducts, ordinarily present in lung, breast, and pancreas tumor tissues and considered to be tumor markers (54). The plants described in this work present a variety of biological activities, but have little scientific support making it necessary to initiate robust research protocols to determine the safety and efficacy of plant-based therapies.

In our survey $65 \%$ of the patients showed positive perception, higher than in similar previous studies; $24.3 \%$ had a positive outcome expressed as tumor reduction, pain relief, allopathic treatment side effects and a sense of well-being (20). No relationship was found between clinical stage and patient's perception, although over $58 \%$ had positive perception. In patients using allopathic and plant-based CAM treatment simultaneously (57\%), it is impossible to discern whether herbal therapy is responsible for the improvement of health condition or if instead, it is an effect of conventional chemotherapy.

It is essential to study interactions between plants commonly used by cancer patients in Colombia conjointly with allopathic medicine treatments, despite the clinicians' beliefs that plant usage is always a low-risk treatment, this is not necessarily true. An example of antagonistic interactions is observed with St. John's herbal tea (Hypericum perforatum) used to treat cancer and depression and can interact with cytochrome P450 (CYP) or P-glycoprotein substrates, causing a plasma reduction of drugs such as irinotecan, imatinib, cyclosporine, indinavir, midazolam, and warfarin (55).

As for the other plants found in the study, it is known that garlic, soy and ginseng have estrogenic activity, promoting mammary tumor growth by binding to estrogen receptors (ER) (56). In addition, it has been reported that garlic and valerian can activate CYP, increasing tamoxifen metabolism and consequently decreasing its plasma concentration and therapeutic effectiveness. In contrast, grapefruit, mint and chamomile are known inhibit CYP consequently increasing drug toxicity by decreasing its metabolic rate even if the latter interactions have not been fully clarified (17).

Plants were commonly obtained by cancer patients in markets and supermarkets $(79 \%)$, similar to a UK report (57). Most patients consume the plants fresh or in juice, while a smaller number consumes as leaf infusions. The preparation and frequency or dosage is generally transferred through oral tradition. 


\section{Conclusion}

In conclusion, CAM use frequency by breast cancer patients in Colombia was within the range reported worldwide, despite distinct differences in type and frequency. The rate of CAM use without physician consent was similar to previous reports. The CAM type most commonly used was plant-based, using plants like anamú, aloe and red berries. CAM therapy is often used simultaneously with allopathic treatment, making it necessary to examine the synergistic or antagonistic effects of such therapies in breast cancer treatment.

\section{Competing interests}

The authors declare that they have no competing interests.

\section{Author's Contributions}

This work was conceived, directed, and coordinated by SF with the collaboration of LAD. LT is the clinical person responsible. MM and LB conducted the statistical analysis of the data and contributed with the design of the survey. All of the authors have read the manuscript and agree with its contents.

\section{Acknowledgments}

The authors thank the patients who agreed to participate in this study. The Faculty of Science of the Pontificia Universidad Javeriana for their support and the Hospital Universitario San Ignacio. The Pontificia Universidad Javeriana funded this work. We thank Dr. Claudia Cifuentes (Pontificia Universidad Javeriana, Bogotá, Colombia) for critical reading of the manuscript.

\section{References}

1. Sánchez R, Vanegas M. Aproximaciones complementarias y alternativas al cuidado de la salud en el Instituto Nacional de Cancerología: Estudio de prevalencia., Rev Colomb Cancerol 2010; 14 (3): 135-143.

2. NCCAM NIH. What Is Complementary and Alternative Medicine. http://nccam.nih.gov/ health/whttiscam.

3. Gulluoglu BM, Cingi A, Cakir T, Barlas A. Patients in Northwestern Turkey Prefer Herbs as
Complementary Medicine after Breast Cancer Diagnosis, Breast Care (Basel) 2008; 3 (4): 269-273.

4. Helyer LK, Chin S, Chui BK, Fitzgerald B, Verma S, Rakovitch E, Dranitsaris G, Clemons M. The use of complementary and alternative medicines among patients with locally advanced breast cancer-a descriptive study, BMC Cancer 2006; 6: 39.

5. Kremser T, Evans A, Moore A, Luxford K, Begbie S, Bensoussan A, Marigliani R, Zorbas H. Use of complementary therapies by Australian women with breast cancer, The Breast 2008; 17 (4): 387394.

6. Mathijssen RH, Verweij J, de Bruijn P, Loos WJ, Sparreboom A. Effects of St. John's wort on irinotecan metabolism, J Natl Cancer Inst 2002; 94 (16): 1247-1249.

7. Li M, Zhang Z, Hill DL, Wang H, Zhang R. Curcumin, a Dietary Component, Has Anticancer, Chemosensitization, and Radiosensitization Effects by Down-regulating the MDM2 Oncogene through the PI3K/mTOR/ETS2 Pathway, Cancer Research 2007; 67 (5): 1988-1996.

8. Jemal A, Bray F, Center MM, Ferlay J, Ward E, Forman D. Global cancer statistics, CA Cancer J Clin 2011; 61 (2): 69-90.

9. Instituto Nacional de Cancerología INC. Anuario Estadístico 2009. www.cancer.gov.co/.

10. Astin JA, Reilly C, Perkins C, Child WL. Breast cancer patients' perspectives on and use of complementary and alternative medicine: a study by the Susan G. Komen Breast Cancer Foundation, J Soc Integr Oncol 2006; 4 (4): 157-169.

11. Blum J, Dieras V, Lo Russo P, Horton J, Rutman O, Buzdar A, Osterwalder B. Multicenter, phase II study of capecitabine in taxane-pretreated metastatic breast carcinoma patients, Cancer 2001; 92: 1759 - 1768.

12. Ganz PA, Desmond KA, Leedham B, Rowland JH, Meyerowitz BE, Belin TR. Quality of life in longterm, disease-free survivors of breast cancer: a follow-up study, J Natl Cancer Inst 2002; 94 (1): 39-49.

13. Morris KT, Johnson N, Homer L, Walts D. A comparison of complementary therapy use Sánchez R, Vanegas M. Aproximaciones complementarias y alternativas al cuidado de la salud en el Instituto Nacional de Cancerología: Estudio de prevalencia., Rev Colomb Cancerol 2010; 14 (3): 135-143.

14. NCCAM NIH. What Is Complementary and Alternative Medicine. http://nccam.nih.gov/ health/whttiscam.

15. Gulluoglu BM, Cingi A, Cakir T, Barlas A. Patients in Northwestern Turkey Prefer Herbs as Complementary Medicine after Breast Cancer Diagnosis, Breast Care (Basel) 2008; 3 (4): 269-273.

16. Helyer LK, Chin S, Chui BK, Fitzgerald B, Verma 
S, Rakovitch E, Dranitsaris G, Clemons M. The use of complementary and alternative medicines among patients with locally advanced breast cancer-a descriptive study, BMC Cancer 2006; 6: 39.

17. Kremser T, Evans A, Moore A, Luxford K, Begbie S, Bensoussan A, Marigliani R, Zorbas H. Use of complementary therapies by Australian women with breast cancer, The Breast 2008; 17 (4): 387394.

18. Mathijssen RH, Verweij J, de Bruijn P, Loos WJ, Sparreboom A. Effects of St. John's wort on irinotecan metabolism, J Natl Cancer Inst 2002; 94 (16): 1247-1249.

19. Li M, Zhang Z, Hill DL, Wang $\mathrm{H}$, Zhang R. Curcumin, a Dietary Component, Has Anticancer, Chemosensitization, and Radiosensitization Effects by Down-regulating the MDM2 Oncogene through the PI3K/mTOR/ETS2 Pathway, Cancer Research 2007; 67 (5): 1988-1996.

20. Jemal A, Bray F, Center MM, Ferlay J, Ward E, Forman D. Global cancer statistics, CA Cancer J Clin 2011; 61 (2): 69-90.

21. Instituto Nacional de Cancerología INC. Anuario Estadístico 2009. www.cancer.gov.co/.

22. Astin JA, Reilly C, Perkins C, Child WL. Breast cancer patients' perspectives on and use of complementary and alternative medicine: a study by the Susan G. Komen Breast Cancer Foundation, J Soc Integr Oncol 2006; 4 (4): 157-169.

23. Blum J, Dieras V, Lo Russo P, Horton J, Rutman O, Buzdar A, Osterwalder B. Multicenter, phase II study of capecitabine in taxane-pretreated metastatic breast carcinoma patients, Cancer 2001; 92: 1759 - 1768.

24. Ganz PA, Desmond KA, Leedham B, Rowland JH, Meyerowitz BE, Belin TR. Quality of life in longterm, disease-free survivors of breast cancer: a follow-up study, J Natl Cancer Inst 2002; 94 (1): 39-49.

25. Morris KT, Johnson N, Homer L, Walts D. A comparison of complementary therapy use between breast cancer patients and patients with other primary tumor sites, The American Journal of Surgery 2000; 179 (5): 407-411.

26. Cui Y, Shu XO, Gao Y, Wen W, Ruan ZX, Jin F, Zheng W. Use of complementary and alternative medicine by Chinese women with breast cancer, Breast Cancer Research and Treatment 2004; 85 (3): 263-270.

27. Yap KPL, McCready DR, Fyles A, Manchul L, Trudeau M, Narod S. Use of Alternative Therapy in Postmenopausal Breast Cancer Patients Treated with Tamoxifen after Surgery, The Breast Journal 2004; 10 (6): 481-486.

28. Catt S, Fallowfield L, Langridge C. What nonprescription treatments do UK women with breast cancer use?, European Journal of Cancer Care 2006;
15 (3): 279-285.

29. McLay J, Stewart D, George J, Rore C, Heys S. Complementary and alternative medicines use by Scottish women with breast cancer. What, why and the potential for drug interactions?, European Journal of Clinical Pharmacology 2011: 1-9.

30. Wanchai A, Armer JM, Stewart BR. Complementary and alternative medicine use among women with breast cancer: a systematic review, Clin J Oncol Nurs 2010; 14 (4): E45-55.

31. Shen J, Andersen R, Albert P, Wenger N, Glaspy J, Cole M, Shekelle P. Use of complementary/ alternative therapies by women with advancedstage breast cancer, $B M C$ Complementary and Alternative Medicine 2002; 2 (1): 8.

32. Hyodo I, Amano N, Eguchi K, Narabayashi M, Imanishi J, Hirai M, Nakano T, Takashima S. Nationwide Survey on Complementary and Alternative Medicine in Cancer Patients in Japan, Journal of Clinical Oncology 2005; 23 (12): 26452654.

33. Molassiotis A, Scott J, Kearney N, Pud D, Magri M, Selvekerova S, Bruyns I, Fernadez-Ortega P, Panteli V, Margulies A, Gudmundsdottir G, Milovics L, Ozden G, Platin N, Patiraki E. Complementary and alternative medicine use in breast cancer patients in Europe, Supportive Care in Cancer 2006; 14 (3): 260-267.

34. Gertz MA, Bauer BA. Caring (Really) for Patients Who Use Alternative Therapies for Cancer, Journal of Clinical Oncology 2003; 21 (9 suppl): 125-128.

35. DiGianni LM, Garber JE, Winer EP. Complementary and Alternative Medicine Use Among Women With Breast Cancer, Journal of Clinical Oncology 2002; 20 (suppl 1): 34-38.

36. Ashikaga T, Bosompra K, O’Brien P, Nelson L. Use of complimentary and alternative medicine by breast cancer patients: prevalence, patterns and communication with physicians, Supportive Care in Cancer 2002; 10 (7): 542-548.

37. Boon H, Stewart M, Kennard MA, Gray R, Sawka C, Brown JB, McWilliam C, Gavin A, Baron RA, Aaron D. Use of complementary/alternative medicine by breast cancer survivors in Ontario: prevalence and perceptions, Journal of Clinical Oncology 2000; 18 (13): 2515.

38. Lee MM, Lin SS, Wrensch MR, Adler SR, Eisenberg D. Alternative Therapies Used by Women With Breast Cancer in Four Ethnic Populations, Journal of the National Cancer Institute 2000; 92 (1): 42-47.

39. Richardson M, Sanders T, Palmer JL, Greisinger A, Singletary SE. Complementary/Alternative Medicine Use in a Comprehensive Cancer Center and the Implications for Oncology, Journal of Clinical Oncology 2000; 18 (13): 2505-2514.

40. Dy GK, Bekele L, Hanson LJ, Furth A, Mandrekar S, Sloan JA, Adjei AA. Complementary and 
alternative medicine use by patients enrolled onto phase I clinical trials, Journal of Clinical Oncology 2004; 22 (23): 4810-4815.

41. Carpenter C, Ganz P, Bernstein L. Complementary and alternative therapies among very long-term breast cancer survivors, Breast Cancer Research and Treatment 2009; 116 (2): 387-396.

42. Nagel G, Hoyer H, Katenkamp D. Use of complementary and alternative medicine by patients with breast cancer: observations from a health-care survey, Supportive Care in Cancer 2004; 12 (11): 789-796.

43. Wyatt G, Sikorskii A, Wills CE, Su H. Complementary and alternative medicine use, spending, and quality of life in early stage breast cancer, Nursing research 2010; 59 (1): 58.

44. Webster S, Mitchell S, Gallimore W, Williams L, Ahmad M. Biosynthesis of Dibenzyl Trisulfide (DTS) from somatic embryos and rhizogenous/ embryogenic callus derived from Guinea hen weed (\&lt;i\&gt;Petiveria alliacea L\&lt;i\&gt;. ) leaf explants, In Vitro Cellular \& Developmental Biology Plant 2008; 44 (2): 112-118.

45. Im SA, Lee YR, Lee YH, Lee MK, Park YI, Lee $\mathrm{S}$, Kim K, Lee CK. In vivo evidence of the immunomodulatory activity of orally administered Aloe vera gel, Archives of pharmacal research 2010; 33 (3): 451-456.

46. Heggie S, Bryant GP, Tripcony L, Keller J, Rose P, Glendenning M, Heath J. A phase III study on the efficacy of topical aloe vera gel on irradiated breast tissue, Cancer nursing 2002; 25 (6): 442.

47. Bhat G, Kudva P, Dodwad V. Aloe vera: Nature's soothing healer to periodontal disease, Journal of Indian Society of Periodontology 2011; 15 (3): 205.

48. Wu AH, Butler LM. Green tea and breast cancer, Molecular Nutrition \& Food Research 2011; 55 (6): 921-930.

49. Satoh K, Sakamoto Y, Ogata A, Nagai F, Mikuriya H, Numazawa M, Yamada K, Aoki N. Inhibition of aromatase activity by green tea extract catechins and their endocrinological effects of oral administration in rats, Food and Chemical Toxicology 2002; 40 (7): 925-933.

50. Nagata C, Kabuto M, Shimizu H. Association of coffee, green tea, and caffeine intakes with serum concentrations of estradiol and sex hormonebinding globulin in premenopausal Japanese women, Nutrition and Cancer 1998; 30 (1): 21-24.

51. Wu AH, Arakawa K, Stanczyk FZ, Van Den Berg D, Koh W-P, Yu MC. Tea and circulating estrogen levels in postmenopausal Chinese women in Singapore, Carcinogenesis 2005; 26 (5): 976-980.

52. Pommier P, Gomez F, Sunyach MP, D'Hombres A, Carrie C, Montbarbon X. Phase III Randomized Trial of Calendula Officinalis Compared With Trolamine for the Prevention of Acute Dermatitis
During Irradiation for Breast Cancer, Journal of Clinical Oncology 2004; 22 (8): 1447-1453.

53. Jimenez-Medina E, Garcia-Lora A, Paco L, Algarra I, Collado A, Garrido F. A new extract of the plant calendula officinalis produces a dual in vitro effect: cytotoxic anti-tumor activity and lymphocyte activation, BMC Cancer 2006; 6 (1): 119.

54. Seeram NP, Adams LS, Zhang Y, Lee R, Sand D, Scheuller HS, Heber D. Blackberry, Black Raspberry, Blueberry, Cranberry, Red Raspberry, and Strawberry Extracts Inhibit Growth and Stimulate Apoptosis of Human Cancer Cells In Vitro, Journal of Agricultural and Food Chemistry 2006; 54 (25): 9329-9339.

55. Sun J, Hai Liu R. Cranberry phytochemical extracts induce cell cycle arrest and apoptosis in human MCF-7 breast cancer cells, Cancer Letters 2006; 241 (1): 124-134.

56. Flis S, Jastrzebski Z, Namiesnik J, Arancibia-Avila P, Toledo F, Leontowicz H, Leontowicz M, Suhaj M, Trakhtenberg S, Gorinstein S. Evaluation of inhibition of cancer cell proliferation in vitro with different berries and correlation with their antioxidant levels by advanced analytical methods, Journal of Pharmacentical and Biomedical Analysis 2012; 62 (0): 68-78.

57. Betancur-Galvis L, Saez J, Granados H, Salazar A, Ossa J. Antitumor and antiviral activity of Colombian medicinal plant extracts, Memórias do Instituto Oswaldo Cruz 1999; 94: 531.

58. Baskar R, Rajeswari V, Kumar TS. In vitro antioxidant studies in leaves of Annona species, Indian journal of experimental biology 2007; 45 (5): 480.

59. Dai Y, Hogan S, Schmelz EM, Ju YH, Canning C, Zhou K. Selective Growth Inhibition of Human Breast Cancer Cells by Graviola Fruit Extract In Vitro and In Vivo Involving Downregulation of EGFR Expression, Nutrition and Cancer 2011; 63 (5): 795-801.

60. Kijima I, Phung S, Hur G, Kwok S-L, Chen S. Grape Seed Extract Is an Aromatase Inhibitor and a Suppressor of Aromatase Expression, Cancer Research 2006; 66 (11): 5960-5967.

61. Sharma G, Tyagi A, Singh R, Chan D, Agarwal R. Synergistic Anti-Cancer Effects of Grape Seed Extract and Conventional Cytotoxic Agent Doxorubicin Against Human Breast Carcinoma Cells, Breast Cancer Research and Treatment 2004; 85 (1): $1-12$.

62. Waffo-Téguo P, Hawthorne ME, Cuendet $M$, Mérillon J-M, Kinghorn AD, Pezzuto JM, Mehta RG. Potential Cancer-Chemopreventive Activities of Wine Stilbenoids and Flavans Extracted From Grape (Vitis vinifera) Cell Cultures, Nutrition and Cancer 2001; 40 (2): 173-179.

63. Shukla Y, Singh R. Resveratrol and cellular 
mechanisms of cancer prevention, Annals of the New York Academy of Sciences 2011; 1215 (1): 1-8.

64. Dussossoy E, Brat P, Bony E, Boudard F, Poucheret P, Mertz C, Giaimis J, Michel A. Characterization, anti-oxidative and anti-inflammatory effects of Costa Rican noni juice (Morinda citrifolia L.), Journal of Ethnopharmacology 2011; 133 (1): 108-115.

65. Wang MY, West BJ, Jensen CJ, Nowicki D, Su C, Palu AK, Anderson G. Morinda citrifolia (Noni): a literature review and recent advances in Noni research, Acta Pharmacologica Sinica 2002; 23 (12): 1127-1141.

66. Wang M-Y, Peng L, Lutfiyya MN, Henley E, Weidenbacher-Hoper V, Anderson G. Morinda Citrifolia (Noni) Reduces Cancer Risk in Current
Smokers by Decreasing Aromatic DNA Adducts, Nutrition and Cancer 2009; 61 (5): 634-639.

67. Borrelli F, Izzo AA. Herb-drug interactions with St John's wort (Hypericum perforatum): an update on clinical observations, The AAPS journal 2009; 11 (4): 710-727.

68. Helferich W, Andrade J, Hoagland M. Phytoestrogens and breast cancer: a complex story, Inflammopharmacology 2008; 16 (5): 219-226.

69. Damery S, Gratus C, Grieve R, Warmington S, Jones J, Routledge P, Greenfield S, Dowswell G, Sherriff J, Wilson S. The use of herbal medicines by people with cancer: a cross-sectional survey, Br J Cancer 2011; 104 (6): 927-933. 